\title{
Teaching Activities to Contribute to the Environmental Education of the Agricultural Engineer
}

\author{
Yendry Llorente Aguilera* Maribel Ramírez Molina Royder García Lang
}

The University of Holguín, Cuba

\begin{tabular}{ll}
\hline ARTICLE INFO & ABSTRACT \\
\cline { 2 - 2 } $\begin{array}{l}\text { Article history } \\
\text { Received: } 1 \text { December } 2020\end{array}$ & $\begin{array}{l}\text { The research aims to develop teaching activities to contribute to the Envi- } \\
\text { ronmental Education of the future Agricultural Engineer at the Municipal } \\
\text { University Center (CUM) Sagua de Tánamo, based on the most up-to- } \\
\text { Accepted: } 8 \text { January } 2021\end{array}$ \\
Published Online: 30 March 2021 & $\begin{array}{l}\text { contribution is given in the proposal of educational activities of an envi- } \\
\text { ronmental nature that involve productive entities, peasants and the family }\end{array}$ \\
Keywords: & itself with the collaboration of community organizations and institutions. \\
environment & Its practical significance consists in the possibility of implementation \\
destruction & by teachers to promote environmental training in students of this career, \\
from the Chemistry discipline, contributing to a greater preparation to & face the existing environmental problems in the territory. The scientific \\
agricultural engineer & novelty lies in the conception used when planning teaching activities, to \\
education teaching activities & actively involve various members of the community in the development \\
of the production process, which will allow to obtain encouraging results & in the teaching-learning process. Theoretical, empirical, experimental \\
methods and documentary review were used. Its practical significance \\
consists in its comprehensive application from a systemic, humanistic \\
and integrating approach to transform the modes of action of students and \\
affects their training.
\end{tabular}

\section{Introduction}

Environmental problems on the planet are increasing and are becoming more worrisome every day ${ }^{[1]}$, for which the adoption of immediate measures is necessary with a view to offering solutions worldwide.

One of the objectives of the economic and social policy of the Cuban State is to raise the standard of living of the population where it focuses its actions on the basis of work guidelines. One of them focuses on emphasizing the promotion of environmental education that is based on the idea that through it, it is possible to give a differentiated treatment to the environment and research in this field, taking into account sustainable development, confronta- tion climate change and the conservation and rational use of natural resources, such as soils, water, beaches, the atmosphere, forests and biodiversity ${ }^{[2]}$.

In this context is the training of the Agronomist Engineer, for whom, according to the bibliography, the first skills that must be developed in his training are related to the diagnosis and identification of the main problems in correspondence with the productivity of the soils, the yield of the crops, the factors that affect it, as well as establishing prediction of the possible results that can be obtained, for which the contents of the General Chemistry subject are required, through the development of tasks that can be solved from the academic component, working and

*Corresponding Author:

Yendry Llorente Aguilera,

The University of Holguin, Cuba;

E-mail: yllorentea@uho.edu.cu 
/ or research, of great importance, since students acquire chemical-environmental knowledge and skills to better assess the risks and benefits and acquire skills to have more information when making decisions regarding technological problems related to their future knowledge.

That is why it is proposed to solve the following problem: How to promote the environmental training of the Agricultural Engineer at the Municipal University Center in Sagua de Tánamo?

In correspondence with this problem, the following topic was determined: Teaching activities to favor the Environmental Education of the Agricultural Engineer.

The following objective is declared: To elaborate teaching activities to contribute to the Environmental Education of the future Agronomist Engineer at the Municipal University Center in Sagua de Tánamo.

To carry out the research, a population of 64 first-year students of the Engineering in Agronomy career was taken into account, the sample includes 64 students, and it was taken intentionally.

The system of methods used in the investigation are the following:

Theoretical methods: Analysis and synthesis, induction - deduction, historical - logical and the systemic approach. Empirical methods: Observation of Joint Activities, parent surveys, interviews.

The practical contribution is given in the proposal of teaching activities, to contribute from the insertion of various tasks of an environmental nature that involve productive entities, farmers, civil servants and all members of the group, the family itself with the collaboration of the organizations and community institutions.

Its practical significance consists in the possibility of implementation by the teachers' proposing teaching activities to promote environmental training in students of the Agronomy Engineering career, from the Chemistry discipline, with an environmental approach, which contributes to the students show greater preparation to face the existing environmental problems in the territory.

The scientific novelty lies in the concept used when planning teaching activities, to actively involve several members of the community in the development of the production process, which will allow to obtain encouraging results in the teaching-learning process of the future Agricultural Engineer.

\section{Developing the Environmental Education}

\subsection{Theoretical Foundations about the Environ- ment}

The existence of the human species depends to a large extent on its ability to maintain the natural balance of the world and on the efficient application of the new advances that technological development is offering in order not to deplete the available resources, for which reason gradual deterioration of nature must be stopped and it is necessary to develop systems that contribute to its regeneration. The global nature of ecological problems and their interdependence with development models are issues accepted in forums and in broad spheres of opinion, it is a difficult issue when it comes to global responsibility, when those responsible are the richest countries, when a many governments care very little about the future of the planet.

\subsection{Main Environmental Problems}

The main global problems affect the quality of life of the peoples, mainly those of the south, most of which have an underdeveloped economy. It is therefore necessary to know them to understand the need to implement a set of measures that transform the modes of action of individuals, in favor of the protection of natural resources and the environment.

Consumer societies are fundamentally responsible for the atrocious destruction of the environment, they were born from the old colonial metropolises and from imperial policies that, in turn, generated the backwardness and poverty that today plague the vast majority of humanity. With only $20 \%$ of the world's population, they consume two-thirds of the metals and three-quarters of the energy produced in the world. They have poisoned the seas and rivers, they have polluted the air, they have weakened and perforated the ozone layer, and they have saturated the atmosphere with gases that alter climatic conditions with catastrophic effects that we are already beginning to suffer [3].

The validity of these words is appreciated, since the oppression of the rich capitalist countries of the north is maintained, which produce manufactured goods and exchange for cheap raw materials with the underdeveloped countries of the south, plunder their natural resources and cause considerable damage to the environment.

A very difficult panorama is really appreciated in the world due to the accumulation of environmental problems, which together with the world crisis endangers life on the planet.

(1) At a global level: Global warming of the atmosphere (greenhouse effect), due to the emission, by industry and agriculture, gases that absorb long-wave radiation reflected by the Earth's surface; The depletion of the ozone layer of the stratosphere, the planet's protective shield, by the action of chemicals based on chlorine and bromine, which allows a greater penetration of ultraviolet 
rays towards its surface; The increasing contamination of waters and soils by the dumping and discharges of industrial and agricultural waste; The depletion of forest cover (deforestation), especially in the tropics, due to the exploitation for firewood and the expansion of agriculture; The loss of species, both wild and domestic, of plants and animals due to the destruction of natural habitats, agricultural specialization and the increasing pressure to the one to which the fishery is subjected; Soil degradation in agricultural and natural habitats, including erosion, ponding, and salinization, leading to the loss of the soil's productive capacity over time. There are other problems such as poverty, drug addiction, the effect of the urban crisis, nuclear risk, armed conflicts, diseases such as AIDS and Influenza A- H1N1 among others.

(2) In Holguín, despite the positive results achieved in previous strategic cycles, difficulties persist in solving the main environmental problems that, among other factors, are associated with: lack of systematicity, discipline and lack of comprehensive approaches, Limited introduction of the results of science, technology and innovation, as well as of the environmental dimension in policies, plans, development programs and land use planning; The lack of culture and environmental sensitivity in society; Limited participation and articulation of actors, both institutional and civil society; Outdated, low effectiveness and little compliance with the current legal framework; Deterioration, inadequacies and lack of integration of environmental monitoring networks; Deficiencies in planning and ranking according to available resources and inadequacies in financing; Not adequate reflection in the national and business accounting of the use of natural resources linked to development programs and production processes, respectively; The impacts of climate change that accentuate the effects on the environment; Appearance of new actors in environmental policy and management; Lack of integration in the management of natural resources between the different Organizations of the Central State Administration (OACE).

It is therefore necessary to know how this problem behaves in the Municipality of Sagua de Tánamo, as a prerequisite for the preparation of teaching tasks. The territory is located in the northeast of the Holguín province, bordered to the north by the Fran País municipality; to the south, with El Salvador from the Guantánamo province; to the east, with Moa; to the west, with the II Front of the Santiago de Cuba province and the Mayarí municipality, it has an area of $702 \mathrm{~km} 2$, of which $545 \mathrm{~km} 2$ correspond to the Sagua river basin. $70 \%$ of the territory corresponds to the Turquino Plan, so most of it is mountainous with conditions for growing coffee and the flat part is made up of fertile soils favorable to agriculture.

34 pollutant sources have a direct impact on the territory, among which are 29 that are considered to be main or extremely active: 29 coffee depulper, 2 minal establishments and the soft drink factory; as well as the extraction of sand and the urban waste system, with emphasis on the appalling situation of the ditches in the low-lying areas, as mosquito breeding sites and highly harmful residues for human health accumulate in them. The aforementioned production centers were built without taking into account the protection of the environment, they dump their waste into the river, directly affecting the quality of the water and biodiversity. The washing of motor vehicles in the river, bathing domestic animals and the extraction of sand cause serious pollution that affects the quality of the water consumed by a large part of the population. The municipality is also affected by the deterioration of the soils, by the incidence of salinization that covers a territory of about 990 acres in the Juan Díaz valley, a situation that causes low production in the production of the banana crop, other aspects that impoverish the quality of the soils are made up of forest fires, which affect the vegetal layer. In addition, there is an increase in logging, pruning, burning and poaching within the protected area by usufructuaries of rustic farms and unscrupulous residents that, as an example, the author illustrates the sanction that the Sagua Ranger Corps has had to apply through fines to offenders.

The coffee depulpers constitute a center where wet and cherry coffee is processed until it is completely dry, in many cases the waste contaminates the waters of streams and rivers.

\subsection{Potentialities of General Chemistry for the Formation of the Agricultural Engineer for Social / Agricultural Development and Environmental Balance}

Chemistry constitutes a fundamental discipline within the career because of its importance for the understanding and mastery of subjects such as plant physiology, soil, plant nutrition, animal nutrition, the use of pesticides, the evaluation and protection of environment, among others; all essential for the professional future.

The problem of the profession that is solved with the discipline lies in establishing the properties of the substances that allow them to be applied for quantitative determinations in agricultural samples, allowing them to achieve an optimal use of the bioproductive capacities of the species object of their work, in harmony with the environment, all of which also presupposes the systematic evaluation of the quality of the products obtained and the state of the ecosystem on which it acts for the production of agricultural prod- 
ucts that satisfy the needs of our society.

The student must first carry out the observation related to the properties and functions of the chemical substances that appear in biotic and abiotic systems, and from there problem situations arise that must be solved by resorting to experimentation. In this way, it determines in practice the essential features that characterize the object with the use of procedures, techniques and analytical methods, to then make generalizations, which will later be applied to the solution of professional problems.

One way to achieve the above is constituted by teaching tasks with a chemical-environmental professional orientation where the student systematizes and contextualizes the content, which allows them to seek ways and solutions to professional problems, also makes their study useful, necessary and essential for this profession develops in them responsible behaviors and equips them with the necessary tools for their future to act.

Environmental Education with the subjects that interact with nature is considered important, to favor a conscious way of acting of these in their interaction with the environment and avoid the application of the law. The University Center in town can influence this purpose because its students live throughout all the popular councils where these problems occur and they are workers of these entities.

On several occasions there are floods in the lower areas of the municipality, it is crossed by ditches that in most cases are dirty, since the neighbors deposit in them waste from corrals, sewage water, garbage, heavy objects etc. In addition, some neighbors still cook with charcoal and sawdust, which pollutes the environment, when the river rises, the evacuation process is carried out an average of 12 times a year and when there is heavy rains, the ditches grow, penetrating homes and work centers.

Another element to consider is the impact that acid rains transported from Moa by the northeast trade winds have on the Sagua de Tánamo environment, especially: sulfur trioxide, sulfur dioxide, nitrogen dioxide, among others, which when put into Contact with water vapor in the atmosphere forms acids and falls as rain.

\subsection{Preparation of Teaching Activities}

In its preparation, it has been considered to address global, national and local environmental problems with an analysis of the problem so that it is meaningful, motivating and interesting to the student.

In these activities the student is reminded and at the same time deepens in the study of problems such as the greenhouse effect, acid rain, deforestation, desertification, the importance of the ozonosphere; how we can take care of her, the international agreements signed for this purpose and compliance with these by the different countries and how then we influence locally with education, awareness and exemplification of the support staff in their behavior in defense of the relationship of man with his environment influencing irreversibly in sustainable development.

Each teaching activity has the same structure: they were outlined taking into account the title of each activity, the form of organization of teaching, place, objective, and variants in some cases. A total of 20 teaching tasks were projected, of which the first 12 were executed in teaching scenarios planned in a conference, the first of the tasks, 10 seminars and a practical class and the remaining 8 in non-teaching settings, all practical classes.

Generally the level of complexity and requirement of the activities; It grows as the number increases from lowest to highest, motivating the creative capacity of the student. The last activities require the student to integrate as many concepts as possible in solving problems that arise in the environment. Other characteristics of the activities are summarized below:

- They have a developing character.

- They allow reflection, assessment, argumentation and lead to decision-making.

- They allow the active participation of the student in the construction of values.

- The content of the activity system is inclusive and allows the establishment of interdisciplinarity.

- The Environmental Education curriculum strategy is carried out.

Title: Waste from coffee pulping machines. A danger!

Form of organization: Practical class.

Objective: To assess the procedure followed for the dumping of waste in an industry through observation and interviews with specialized personnel.

For the economic-social development, the territory of Sagua has 29 coffee depulping plants, however, they constitute polluting sources that are considered as main or extremely active.

(1)-Investigate with the manager of the coffee depulper closer to your home how and where the waste is dumped after processing the grain.

(2)-Visit the place where these wastes are going to stop and observe the security measures that are taken in these. Make a report where you make an assessment according to the data obtained.

(3)-Make an informative mural where the security measures taken in the premises where this product is processed are reflected.

(4)- Write a message to a student from another center where you express what efforts are necessary to make to 
counteract the pollution of the river due to the irrational dumping of toxic and harmful substances in them.

(5)-Expose the work done in the workshop that will be done at the closing of the unit.

\section{Conclusions}

Environmental Education for sustainable development constitutes an important contribution to changes in the conception of man about himself, his place in the world and his relationship with Nature, essential conditions for his training and professional exercise oriented to the sustainable development of the farming.Chemistry, due to the potential offered by its contents, offers the possibility of training agronomists capable of becoming aware of their environment and gaining experience, forming values that allow them to act individually and collectively, to transform and solve current and future ecological problems. .The proposal of teaching tasks with a chemical-agricultural-environmental orientation contributes to perfecting scientific thinking that allows them, together with the development of professional skills, to actively guide themselves in the conception, execution and direction of the labor process where they will be inserted as future professionals.

\section{Bibliographic References}

[1] Transforming Our World": the 2030 Agenda for Sustainable Development" United Nations General Assembly, September 25, 2015

[2] Ministry of Science, Technology and Environment., C.I.T.M.A., 1997. National Environmental Strategy.

[3] Castro, F. (1992). Speech at the United Nations Conference on Environment and Development. Rio de Janeiro. Havana. Political Editor.

\section{Bibliography}

[1] Blanco, J. (2004). Inorganic Chemistry 1 (I and II). Havana: Editorial Pueblo y Educación, City of Havana

[2] Castro, F, (2002). Speech delivered at the Millennium Summit. (Tabloid).

[3] CUBA. (1997) Ministry of Science, Technology and Environment. National Strategy for Environmental Education. - Havana: CITMA - UNESCO.

[4] Cuenca, G. (2008). Environmental education towards an integrated approach to knowledge in the area of Natural Sciences. Thesis option to the title of Master in Education Sciences. ISP "José de la Luz y Caballero". Holguin. -

[5] Gligo, V. (2006). Styles of development and environment in Latin America, a quarter of a century later,
CEPAL, SIDA, Santiago de Chile.

[6] Lara, A.R (1986). General chemistry. Editorial. People and Education.

[7] León, A. (1991). Rafael Superior General Chemistry. Editorial Pueblo y Educación. Havana. Query text.

[8] Mc. Pherson, M. () and others. Environmental Education in teacher training. Editorial Pueblo y Educación, City of Havana.

[9] Méndez, A. (2008). Methodology for the teaching - learning of biodiversity as a teaching - research process, in the area of Natural Sciences, in high school. ISP "José de la Luz y Caballero". Holguin

[10] Núñez, C. (2003). The education of environmental attitudes in students of the specialty of Industrial Chemistry in Technical and Professional Education. Thesis (Doctor of Pedagogical Sciences). ISP "José de la Luz y Caballero". Holguin.

[11] Núñez, J. and others. (2014) For what science, technology and society in universities? Santiago de Guayaquil Catholic University. Ecuador.

[12] Núñez, J. (1999). Science and technology as social processes. Editorial Félix Varela. Havana.

[13] Ponjuan, A. (1986). Inorganic chemistry. Ed. People and Education. Havana.

[14] Proenza, J. (1998). Curricular strategy to implement Environmental Education in the specialty of Chemistry of the ISP "Blas Roca Caldario". In II International Congress of Chemistry. Havana.

[15] Valdez, O. (1996). Environmental Education in the educational teaching process in the mountains of Cuba. Thesis (Doctor in pedagogical sciences,) Havana.

[16] Zilberstein, J. (1991). Biology 5: Twelfth Grade: Textbook. Part 1. Editorial Pueblo y Educación.

[17] Official Gazette of the Republic of Cuba. Guidelines of the Economic and Social Policy of the Party and the Revolution for the period 2016-2021.

[18] Núñez, J, (1994). Science Technology and Society. In Social Problems of Science: Editorial. Felix Varela. Havana.

[19] Núñez, J. (1999). Science and Technology as Social Processes. What science education should not forget. Havana, Editorial Félix Varela.

[20] Bayón M, (2002). Environment. Sustainable Development and Education, In Education No 105, Havana.

[21] Valdés, O. (2002). Environmental Education and protection of the Environment. In Education No 105, Havana.

[22] Piñero, O. (2003). Didactic alternative to favor the environmental dimension in the teaching of Natural Sciences in Basic Secondary. Doctorate in Pedagogical Sciences. 